Europe PMC Funders Group

Author Manuscript

Curr Opin Endocrinol Diabetes Obes. Author manuscript; available in PMC 2012

December 01.

Published in final edited form as:

Curr Opin Endocrinol Diabetes Obes. 2012 June ; 19(3): 220-227. doi:10.1097/MED.

0b013e3283534b11.

\title{
Pharmacogenetics of FSH action
}

\author{
Maris Laan, \\ Human Molecular Genetics Research Group, Institute of Molecular and Cell Biology, University of \\ Tartu, Tartu, Estonia
}

Marina Grigorova, and

Human Molecular Genetics Research Group, Institute of Molecular and Cell Biology, University of Tartu, Tartu, Estonia

\author{
Ilpo T. Huhtaniemi \\ Department of Surgery and Cancer, Institute of Reproductive and Developmental Biology, \\ Hammersmith Campus, Imperial College London, United Kingdom
}

\section{Abstract}

Purpose of the review-To review the current knowledge of genetic variants in the two genes affecting the individual responsiveness to follicle-stimulating hormone (FSH) action-the FSH beta-subunit $(F S H B)$ and the FSH receptor $(F S H R)$, as well as the pharmacogenetic ramifications of the findings.

Recent findings-Four common variants in FSHB/FSHR were shown to exhibit significant effect on FSH action: linked FSHR variants Thr307Ala and Asn680Ser determining common receptorisoforms, andgene expression affecting polymorphisms FSHR-29G/A and FSHB-211G/ T. In women, the FSHR Thr307Ala/Asn680Ser polymorphisms show consistent predictive value for estimating the most optimal $\mathrm{rFSH}$ dosage in controlled ovarian hyperstimulation $(\mathrm{COH})$. The same variants exhibit a potential for the pharmacogenetic assessment of the treatment ofPCOS. The FSHR-29G/A variant was also shown to contribute to ovarian response to COH. Pilot studies have suggestedthe $F S H B$-211TT-homozygous oligozoospermicmen with genetically determined low concentration of FSH, as potentially the best responders to FSH treatment; furthermore, modulation of this response by FSHR polymorphisms is possible.

Summary-Genetic variants in FSHB/FSHRexhibit a potential for pharmacogenetic applications in selecting appropriate treatment options (timing and dosage) in male and female conditions requiring or benefitting from FSH therapy.

\section{Keywords}

Follicle-Stimulating Hormone; FSHB-211G/T SNP; FSHRThr307Ala/Asn680Ser; FSHR-29G/A SNP; pharmacogenetics

Correspondence to Maris Laan, Institute of Molecular and Cell Biology, University of Tartu, Riia 23, 51010 Tartu, Estonia; Tel: +372-7375008; maris.laan@ut.ee.

The authors declare no conflict of interest.

This is a PDF file of an unedited manuscript that has been accepted for publication. As a service to our customers we are providing this early version of the manuscript. The manuscript will undergo copyediting, typesetting, and review of the resulting proof before it is published in its final citable form. Please note that during the production process errors may be discovered which could affect the content, and all legal disclaimers that apply to the journal pertain. 


\section{Introduction}

Follicle-stimulating hormone (FSH) together with the other gonadotrophic hormone, luteinizing hormone ( $\mathrm{LH})$, is produced by the anterior pituitary gland, and it acts along the hypothalamic-pituitary-gonadal (HPG) axis to regulate the crucial functions of the ovary (female sex steroid production and follicular maturation) and testis (spermatogenesis) (Fig. 1) $[1,2]$.Today, treatments with recombinant $\mathrm{FSH}(\mathrm{rFSH})$ are a mainstay in several areas of reproductive medicine. Knowledge is accumulating that the efficiency of $\mathrm{rFSH}$ therapy is modulated by polymorphisms ingenes regulating the dynamics of FSH action.

\section{Function of FSHin women and men}

In women, pulsatilegonadotropin-releasing hormone $(\mathrm{GnRH})$ secretion from the hypothalamus maintains similarly pulsatile secretion of FSH andLH from the anterior pituitary, anddrivesin the ovary thehormonal and cellular events that regulate the maturation of Graafian follicles and granulosa cell estrogen production. FSH is also essential to prevent apoptosis and to stimulate proliferation of granulosa cells. Knockoutfemale mice lacking FSHor FSH receptor (FSHR) exhibit infertility, small ovaries, blockage in folliculogenesis, defects in granulosa cell proliferation and function, and suppressed aromatase activity $[3,4]$, and provide accurate phenocopies for similar mutations in women. Outside reproduction, and quite surprisingly, recent studies have suggested a possible extragonadal role of FSH in postmenopausal bone loss $\left[5,6^{*}\right]$ and in the neovascularization surrounding malignant tumours [7*]. More data is required to draw the conclusions on extragonadal actions of FSH.

In men, GnRH regulates similarlythe pulsatile secretion of LH and FSH. Lower responsiveness to GnRH pulsatility in men has been explained by androgen exposureduring embryonic developmentleading to different functionality of the hypothalamic GnRH system [8]. In the male,FSHRs are located in testicular Sertoli cells. During fetal, neonatal and pubertal development, FSH activates the proliferation of Sertoli cellsthat is crucial for normal testes development and promotes mitosis in spermatogonia [9*,10*]. In adult men, FSH is important for the maintenance of the metabolic functions of Sertoli cellsthat are essential for the maintenance of qualitatively and quantitatively normal spermatogenesis, germ cell survival and male fertility [11,12]. In male mice, FSH $\beta$-subunit or FSHR deficiency did not lead to infertility, although the animals displayed decreased Sertoli cell number, reduced testes size, sperm count and motility [3]. Interestingly, in menthe inactivating FSHR mutationsrepresent phenocopies of murine $f s h b$ and $f s h r$ knockouts, but thehuman FSHB inactivation induces a more extreme phenotype (azoospermia) compared to male mice, for a so far unknown reason. More information is thus also needed to improve our knowledge on the FSHactions in men.

\section{Key genes involved in FSH action}

The efficiency of FSH action is regulated by threemain factors-the intrinsic bioactivity of the hormone, its serum concentration, andthe efficacy of FSHR signal transduction in response to hormonal stimulation. The rate-limiting step in FSH production is the transcription of the FSH beta subunit coding FSHBgene [13]. The other component in the biologically active FSH heterodimer, the common alpha subunit, is produced normally in excess and is not known to limit the production of bioactive FSH[14]. Activation of FSH receptor coded by the FSHR gene is necessary for the hormonal functioning of FSH[15]. Other genetic variants affecting FSH action may localize in genes involved in the HPG axis either upstream (e.g. GnRH, INHBA, INHBB) or downstream (e.g. CYP19A1, ESR1, $E S R 2$, etc.) of the pituitary level (Fig. 1), but their clinical value in pharmacogenetic applications requires further studies. 


\section{Follicle stimulating Hormone beta subunit gene (FSHB)}

The human FSHB gene (MIM: 136530, chr. 11p13, gene 4262 bp, protein 119 amino acids) belongs to the glycoproteinhormone (LH, FSH, TSH) beta gene family $(G t H B)$ and is expressed in gonadotroph cells within the anterior pituitary gland [16**].It is characterized by a low number of polymorphisms mostly within noncoding regions and spread as highfrequency alleles in human populations (Fig. 2A). These variants arein strong linkage disequilibrium (LD)with each otherand form two main FSHBhaplotypes [17].

Only five inactivating $F S H B$ mutations (all in exon 3 ) have been reported in nineindividuals (Fig. 2A)(reviewed in [16**]). These mutations result in premature stop-codon or loss of a cysteine residue affectingproper subunit folding. Homozygous or compound heterozygousfemale patients exhibited impaired pubertal development and primary amenorrhea.Male patients had normal or impaired puberty and azoospermia.

A regulatory SNP within the FSHB promoter $-211 \mathrm{G} / \mathrm{T}$ (rs10835638) is the only identified genetic variant with direct major effect on serum FSH concentrations in men. In Estonians, the median serum FSH of TT- compared to GG-genotype carriers was in young men78\%[18] and among infertility patients $48.5 \%$ of control levels [19**].The association of the T-allele with reduced serum FSH was confirmed in a large cohort of Baltic young men [20**], as well as in Italian [21**] and German [22] infertility patients. The reduction incirculating FSH levels wasaccompanied by significantly reduced serum Inhibin B and testosterone, as well asby lower testis size and sperm concentration(Fig. 2B).Genetically determined low concentrationof FSHduring development might affecttesticular cell proliferation and lead to impaired testicular function. Increasedfrequency of theT-allele in Estonian infertility patientssuggesteda possible contribution of the FSHB gene position $211 \mathrm{G} / \mathrm{T}$ to the male reproductive potential.

In addition, the C-allele of anFSHBsynonymous change (2623T/C, Tyr58Tyr, exon 3, rs6169; Fig. 2A) has been associated with anincreased risk for polycystic ovarian syndrome (PCOS) [23] and with later age at menarche[24].

\section{Follicle stimulating Hormone Receptor gene (FSHR)}

The human FSHR gene (MIM:136435, chr. 2p21, gene $192 \mathrm{~kb}$, protein 695 amino acids) encodes for FSH receptorthat belongstogether with LHR and TSHRto the glycoprotein hormone receptor subfamily of the G-protein coupled receptors (GPCRs)[15]. FSHR is primarily expressed in ovarian granulosa and testicular Sertoli cells, but its expression in endometrium [25], osteoclasts [5] and vascular endothelium surrounding malignant tumours [7*] has recently been reported.Of the $>1300$ SNPs in the FSHR gene, eight (six nonsynonymous) locate in the coding region (Fig. 3).

Activating FSHRmutationslead toconstitutively activereceptor signalling in the absence of hormone bindingdue to a conformational alteration of the transmembrane domain(Fig. 3; reviewed in [26*]). In the single man found with such a mutation (Asp567Gly), the phenotype was persistent spermatogenesis in the absence of circulating gonadotrophins (after hypophysectomy)[27].This clinical phenotype has been reproduced in transgenic mutant male mice $[28,29]$. In heterozygous women with such mutations the phenotype ispregnancy-associated ovarian hyperstimulation, mainly due to responsiveness of the mutated receptor to hCG. In female mice, gain-of-function fshr mutations lead to distinct pathological changes in ovarian structure and function, e.g. accelerated loss of follicles[30]. Inactivating FSHR mutations caused in men impaired spermatogenesis and in womenhypergonadotropic ovarian failure[26*]. 
Most of the functional studies on FSHR polymorphisms have concernedtwo substitutions in exon 10,Thr307Ala (rs6165) and Asn680Ser (rs6166)[31]. These polymorphisms are instrong LD and exhibit almost equal distribution of the two main isoform variants (Thr307Asn680, Ala307-Ser680) in Europeans.As FSHRisoforms differ in sensitivitytoFSH stimulation, they havea significant effecton female serum FSHconcentration and ovarian FSHRresponse $\left[32,33,34^{*}, 35^{* *}, 36^{*}\right]$. Women with the Ser680/Ser680 genotype exhibit longer menstrual cycles as another sign of reduced ovarian response to FSH [37]. In addition, in Taiwanese women the FSHRAsn680 variantwas reported to reducethe risk ofendometriosis [38], andin Italian women the Ala307-Ser680 gene variant homozygosity (least sensitive receptor) was associated with lower risk to Alzheimer disease [39]. In contrast, no effectsof FSHR Thr307Ala and Asn680Ser variants on adult male serum FSH and efficiency of spermatogenesis have been proven. Additionally, the carrier status of the FSHRisoforms has been suggested to influencethe susceptibility to testicular $\left[34^{*}, 40\right]$ and ovarian cancer[41-43], but due to a small number of studies no clear-cut associations or definitive conclusions can be drawn.

Anovel FSHRpolymorphism -29G/A (rs1394205) located in the 5'-UTR was shownto alter the transcriptional activity, and it was associated with female hypertension [44].A recent study demonstrated significantly reduced FSHR at mRNA and protein level in granulosa cells of subjects with $F S H R-29$ minor A-allele homozygosity compared toG-allele homozygotes [ $45^{* *}$ ].The FSHR-29 AA-genotype was significantly enriched among Indian women with primary or secondary amenorrhea compared to normally cycling fertile women, and the AA-subjects with primary amenorrhea exhibited increased serum FSH levels consistent with inadequate receptor stimulation [46*].Reduced testis volume and slightly lower sperm counts inFSHR-29 A-allele male carriers has also been reported[47].

AsFSHR is a large gene, it may contain several other functional variants in addition to the few studied SNPs. A recent genome-wide association study (GWAS) pinpointed anFSHRintronic SNP (rs2268363) being associated with the development of erectile dysfunction in African-American men after radiotherapy for prostate cancer [48].A significant association of several FSHR polymorphisms was detected with preterm birth [49].

\section{Pharmacogenetic potential of FSHB and FSHR gene variants}

Serum FSH level are measured for the assessment of fertility potential and gonadal function. In both sexes, abnormal serum FSH level suggests impaired gonadal function.Low FSH indicates a deficiency in the hypothalamic GnRH secretion or pituitary gonadotrophin synthesis and/or secretion(Fig. 1). Gonadotrophin levels are inadvertently high in primary gonadal failure due to insufficient negative feedback of gonadal sex steroids and/or inhibin. In the clinical diagnostic utility the correct interpretation of estimated serum FSH (as abnormally low or high) is not always straightforward as automated commercial immunoassays exhibit between-method sensitivity and measurement variability [50].An option to treatdeficient gonadotrophin secretion is non-invasive medication by FSH injections or pulsatile GnRH infusions. Another common application of FSH treatment is during ovarian priming for in vitro fertilization (IVF) treatment.

\section{Pharmacogenetics of disturbed action of FSH in women Polycystic ovary syndrome (PCOS)}

PCOSrepresents a common clinical condition (6-10\% of women) characterized by unbalanced FSH (normal or reduced) levels in relation to LH (increased).It results in increased LH/FSH ratio and excessive ovarian androgen production causing impaired 
menstrual cycle,ovulatory dysfunction and symptoms of androgen excess (e.g. hirsutism) [51,52]. Familial disposition to the syndrome suggests a genetic risk [53]. Biological evidence, and candidate gene and genome-wide association studies point to the link between PCOS andpolymorphisms in gonadotrophin and their receptor genes [54,55**,56]. Metaanalysis across eight studies showed significant reductionin PCOS risk in homozygotes for the FSHR Asn680/Asn680 major isoform(OR= 0.639; 95\%CI: 0.416, 0.980) [57*].

Treatment of infertility ofPCOS patients consists of ovulation induction byclomiphene citrate (CC) and/or rFSH. PCOS patients homozygous for the FSHRSer680 alleleexhibited high resistance to CC [58]. Consistent with the impaired FSH action, anovulatory (46\%) compared to oligo-ovulatory (10\%) PCOS patients were shown to have a higher chance of pregnancy after ovulation induction with $\mathrm{rFSH}$, whereas $\mathrm{CC}$ treatment was less effective [59]. Interestingly, ina recent study in Italian PCOS women the FSHRAla307Thr heterozygotesexhibited a higher ovarian responsiveness to exogenous rFSH than subjects homozygous for FSHR isoforms [60].

\section{Premature ovarian failure/insufficiency(POF, POI)}

In 1-2\% of women, this is a condition accompanied by elevated FSH levels due to impaired ovarian response to FSH-stimulation [61,62]. There is no clear association or pharmacogenetic perspectivein the conducted studies targeting the FSHRAla680Servariant [34*,57*]. Recently, epistasis betweenFSHRAsn680Ser and polymorphisms in CYP19A1 (aromatase) was associated with POF [63**].

The pharmacogenetic relevance of the $F S H R-29 \mathrm{G} / \mathrm{A}$ and $F S H B-211 \mathrm{G} / \mathrm{T}$ polymorphisms in PCOS and POF patients remainsto be studied.

\section{Postmenopausal hormone therapy and osteoporosis}

In postmenopausal women, FSHR Asn680Ser Asn/Asn-individuals have an increased risk of osteoporosis[64*].Still, the direct effect of FSH on bone must first be confirmed in human before any pharmacogenetic studiesof polymorphisms modulating FSHactionare relevant.

\section{Pharmacogenetics of FSH action in ovulation induction in assisted reproduction}

\section{Controlled ovarian hyperstimulation $(\mathrm{COH})$}

Identification of predictive factors of ovarian response is important in order to apply the most optimal schemes of ovulation induction and ovarian stimulation resulting in high rates of good-quality oocyte recovery and pregnancies, withminimalside-complications of the treatment to the patients. Currently, the FSHR Thr307Ala, Asn680Serpolymorphisms are the only oneswithreliable consistent predictive value andpotentially applicable in clinical tests for estimating the required $\mathrm{rFSH}$ dosage in COH.The Ala307-Ser680 variant is associated with elevated FSH requirement, reduced $\mathrm{COH}$ outcome and lower clinical pregnancy rate, whereas Thr307-Asn680 is associated with good response during $\mathrm{COH}\left[32,33,34^{*}, 45^{* *}\right.$, $\left.65^{*}\right]$. However, no clear conclusions can yet be drawn from the available data on association of the FSHR Asn680Ser and ovarian hyperstimulation syndrome (OHSS) affecting up to 5\% of patients undergoing IVF $\left[26^{*}, 34^{*}, 35^{* *}, 65^{*}, 66\right]$.

AnFSHRpromoter polymorphism -29G/A (rs1394205) mayalso contribute to ovarian response to $\mathrm{COH}$. A seminal study showed that FSHR-29 AA-homozygous women with lowerFSHRexpression required higher dosesof FSH for ovulation induction [67].A followup study revealed that almost $72 \%$ of subjects with the AA-genotype were poor ovarian responders[45**]. In addition to SNPs, the variability in response to $\mathrm{FSSH}$ treatment in $\mathrm{COH}$ 
may be modulated by FSHRvariants due to alternative splicing. Deletion of exon 2 was associated with low response to FSH and deletion of exon 6 with high response [68*]. Abnormal FSHR splice variants were identified in $30 \%$ of young patients.However, the profiling of splice variants in routine molecular diagnostics and pharmacogenetics applications might be challenging.

No data is available on the role of the $F S H B-211 \mathrm{G} / \mathrm{T}$ SNP in determination of the outcome of $\mathrm{COH}$.

\section{Pharmacogenetics of FSH action in men Idiopathic infertility}

It has been claimedthat FSH treatment of male infertility could be performed on selected patients utilizing some predictive parameters able to identify a priori responders with high probability $[69,70]$. For example, elevated plasma levels of FSH have been shown as a negative predictor for the usefulness of FSH treatment. Grigorova et al. [19**] suggested that one potential group of responders to the FSH therapy may be men diagnosed with idiopathic infertility, but exhibiting genetically inherited, constitutively lower serum FSH. Determination of the genotype of the $F S H B$ promoter polymorphism $(-211 \mathrm{G} / \mathrm{T})$ could potentiallyallow identification ofthe patients, whose primary cause of the infertility problems may be inadvertentlylow FSH production (Fig.2). The results of the first pilot study following this hypothesisshowed that Italian infertile men carrying the FSHB-211 Tallele were the best responders to FSH treatment [21**].All patients (9/9) in the TThomozygote group responded to FSH treatment positively. Among the GG-homozygotes and GT-heterozygotesthe fraction of men that increased their sperm count after FSH therapy was $34.2 \%(13 / 38)$ and $65.0 \%(13 / 20)$, respectively.

Another pilot pharmacogenetic study has suggested that response to FSH treatment is may be further modulated by FSHR isoforms. Onlythe carriers of FSHR Ala307-

Ser680allelewere reported withimprovedspermparameters [71**].

\section{Timing of treatment in cases of genetically altered FSH action}

Recently, it has been suggested that neonatal gonadotrophin therapy, instead of treatment in adulthood might have additional benefits [72**].As an example, in boys diagnosed with congenital hypogonadotropic hypogonadism at birth, prepubertal treatment had positive effect in testicular endocrine function and on genital development and growth, which could potentially improve the response to spermatogenesis inducing treatments in adulthood [73].

\section{Conclusion}

The previously established FSHRThr307Ala/Asn680Ser variant, as well as the other more recently identified polymorphisms $(F S H B-211 \mathrm{G} / \mathrm{T}, F S H R-29 \mathrm{G} / \mathrm{A})$ provide convincing evidence for their functional relevance in men and women. These polymorphisms exhibit a potential for pharmacogenetic applications inselecting appropriate treatment options in conditions requiring or benefitting from FSHtherapy.

\section{Acknowledgments}

We thank Dr. Margus Punab and Dr. Kristiina Rull for critical reading of the manuscript, especially from the clinician's point of view.

The studies on the gonadotropin beta subunit genes in the laboratory of Maris Laan have been supported by Wellcome Trust International Senior Research Fellowship (070191/Z/03/A) in Biomedical Science in Central 
Europe, HHMI International Scholarship Grant \#55005617, Estonian Science Foundation (grants \#7471, \#9030), and Estonian Ministry of Education and Science core grantsSF0182721s06, SF0180022s12.

Financial support:

The studies on the gonadotropin beta subunit genes in the laboratory of Maris Laan have been supported by Wellcome Trust International Senior Research Fellowship (070191/Z/03/A) in Biomedical Science in Central Europe, HHMI International Scholarship Grant \#55005617, Estonian Science Foundation (grants \#7471, \#9030), and Estonian Ministry of Education and Science core grantsSF0182721s06, SF0180022s12.

\section{References and recommended reading}

1. Weinbauer, GF.; Luetjens, CM.; Simoni, M.; Nieschlag, E. Physiology of testicular function. In: Nieschlag, E.; Behre, HM.; Nieschlag, S., editors. Andrology: Male reproductive health and dysfunction. 3rd edition. Springer-Verlag Berlin Heidelberg; Springer: 2010. p. 11-61.

2. Edson MA, Nagaraja AK, Matzuk MM. The mammalian ovary from genesis to revelation. Endocr Rev. 2009; 30:624-712. [PubMed: 19776209]

3. Kumar TR, Wang Y, Lu N, Matzuk MM. Follicle stimulating hormone is required for ovarian follicle maturation but not male fertility. Nature Genetics. 1997; 15:201-204. [PubMed: 9020850]

4. Huhtaniemi I. Mutations along the pituitary-gonadal axis affecting sexual maturation: novel information from transgenic and knockout mice. Mol Cell Endocrinol. 2006; 254-255:84-90. [PubMed: 16730882]

5. Sun L, Peng Y, Sharrow AC, et al. FSH directly regulates bone mass. Cell. 2006; 125:247-260. [PubMed: 16630814]

* 6. Allan CM, Kalak R, Dunstan CR, et al. Follicle-stimulating hormone increases bone mass in female mice. Proc Natl Acad Sci U S A. 2010; 107:22629-22634. [PubMed: 21149714] In this study, transgenic expression of human FSH in GnRH-deficient hypogonadal female mice stimulated an increase in boss mass through an ovary-dependent pathway.

* 7. Radu A, Pichon C, Camparo P, et al. Expression of follicle-stimulating hormone receptor in tumor blood vessels. N Eng J Med. 2010; 363:1621-1630. This study on 1336 patients provide evidence for FSHR expression on the surface of the blood vessels of prostate, breast, colon, pancreas, urinary bladder, kidney, lung, liver, stomach, testis, and ovary tumours.

8. Bliss SP, Navratil AM, Xie J, Roberson MS. GnRH signaling, the gonadotrope and endocrine control of fertility. Front Neuroendocrinol. 2010; 31:322-340. [PubMed: 20451543]

* 9. O'Shaughnessy PJ, Fowler PA. Endocrinology of the mammalian fetal testis. Reproduction. 2011; 141:37-46. [PubMed: 20956578] The complete and recent review regarding hormonal regulation of fetal and neonatal testis development.

* 10. Ruwanpura SM, McLachlan RI, Meachem SJ. Hormonal regulation of male germ cell development. J Endocrinol. 2010; 205:117-131. [PubMed: 20144980] The review concentrated on endocrine regulation of male germ cell development, biochemical and molecular mechanisms of germ cell apoptosis, and role of FSH and testosterone in spermatogenesis.

11. Nieschlag E, Simoni M, Gromoll J, Weinbauer GF. Role of FSH in the regulation of spermatogenesis: clinical aspects. Clin Endocrinol (Oxf). 1999; 51:139-146. [PubMed: 10468980]

12. Plant TM, Marshall GR. The functional significance of FSH in spermatogenesis and the control of its secretion in male primates. Endocr Rev. 2001; 22:764-786. [PubMed: 11739331]

13. McNeilly AS, Crawford JL, Taragnat C, et al. The differential secretion of FSH and LH: regulation through genes, feedback and packaging. Reproduction Suppl. 2003; 61:463-476.

14. Corless CL, Bielinska M, Ramabhadran TV, et al. Gonadotropin alpha subunit. Differential processing of free and combined forms in human trophoblast and transfected mouse cells. J Biol Chem. 1987; 262:14197-14203. [PubMed: 3115988]

15. Simoni M, Gromoll J, Nieschlag E. The follicle-stimulating hormone receptor: biochemistry, molecular biology, physiology, and pathophysiology. Endocr Rev. 1997; 18:739-773. [PubMed: 9408742]

** 16. Nagirnaja L, Rull K, Uusküla L, et al. Genomics and genetics of gonadotropin beta-subunit genes: Unique FSHB and duplicated LHB/CGB loci. Mol Cell Endocrinol. 2010; 329:4-16. 
[PubMed: 20488225] The comprehensive review focused on the evolution, structure as well as common and pathological genetic variation of gonadotrophin beta-subunit coding genes.

17. Grigorova M, Rull K, Laan M. Haplotype structure of FSHB, the beta-subunit gene for fertilityassociated follicle-stimulating hormone: possible influence of balancing selection. Ann Hum Genet. 2007; 71:18-28. [PubMed: 17227474]

18. Grigorova M, Punab M, Ausmees K, Laan M. FSHB promoter polymorphism within evolutionary conserved element is associated with serum FSH level in men. Hum Reprod. 2008; 23:2160-2166. [PubMed: 18567894]

** 19. Grigorova M, Punab M, Poolamets O, et al. Increased Prevalance of the $-211 \mathrm{~T}$ allele of follicle stimulating hormone (FSH) beta subunit promoter polymorphism and lower serum FSH in infertile men. J Clin Endocrinol Metab. 2010; 95:100-108. [PubMed: 19897680] The study replicated highly significant association of the FSHB-211(rs10835638) SNP with male FSH in Estonian male infertility patients, which was demonstrated previously in Estonian young men cohort. Minor T-allele homozygosity was significantly enriched among infertility patients $(2.4 \%$ versus $1.1 \%$ ). Authors suggested $F S H B-211 \mathrm{G} / \mathrm{T}$ as a new potential pharmacogenetic variant associated with male infertility and altered male reproductive parameters.

** 20. Grigorova M, Punab M, Zilaitienė B, et al. Genetically determined dosage of folliclestimulating hormone (FSH) affects male reproductive parameters. J Clin Endocrinol Metab. 2011; 96:E1534-E1541. [PubMed: 21733993] Screening of a large cohort of Baltic young men $(\mathrm{n}=1054)$ showed that genetically determined low FSH level in FSHB-211 T-allele carriers exhibitedsignificant downstreameffects on male reproductive parameters resulting in reduced total testes volume,sperm concentration, Inhibin B and total testosterone levels.

** 21. Ferlin A, Vinanzi C, Selice R, et al. Toward a pharmacogenetic approach to male infertility: polymorphism of follicle-stimulating hormone beta-subunit promoter. Fertil Steril. 2011; 96:1344-1349. e2. [PubMed: 22000911] This study demonstrates that the response to FSH therapy (increase in Inhibin B level and number of total motile sperm) in men with $F S H B-211$ TT-genotype is significantly higher compared to the carriers of the $\mathrm{G}$ allele.

22. Tüttelmann F, Terwort N, Laan M, Gromoll J. FSHB promotor polymorphism influences male reproductive parameters. J Reproduktionsmed Endokrinol. 2011; 8:305-345.

23. Tong Y, Liao WX, Roy AC, Ng SC. Association of AccI polymorphism in the follicle-stimulating hormone beta gene with polycystic ovary syndrome. Fertil Steril. 2000; 74:1233-1236. [PubMed: 11119757]

24. He C, Kraft P, Chasman DI, et al. A large-scale candidate gene association study of age at menarche and age at natural menopause. Hum Gen. 2010; 128:515-527.

25. La Marca A, Carducci Artenisio A, Stabile G, et al. Evidence for cycle-dependent expression of follicle-stimulating hormone receptor in human endometrium. Gynecol Endocrinol. 2005; 21:303306. [PubMed: 16390776]

* 26. Lalioti MD. Impact of follicle stimulating hormone receptor variants in fertility. Curr Opin Obstet Gynecol. 2011; 23:158-167. [PubMed: 21372710] This is a complete review regarding the literature addressing the effects of FSHR mutations and polymorphisms (i.e. splicing variants, common variation) on male and female fertility.

27. Gromoll J, Simoni M, Nieschlag E. An activating mutation of the follicle stimulating hormone receptor autonomously sustains spermatogenesis in a hypophysectomized man. J Clin Endocrinol Metab. 1996; 81:1367-1370. [PubMed: 8636335]

28. Allan CM, Garcia A, Spaliviero J, et al. Maintenance of spermatogenesis by the activated human (Asp567Gly) FSH receptor during testicular regression due to hormonal withdrawal. Biol Reprod. 2006; 74:938-944. [PubMed: 16452461]

29. Allan CM, Lim P, Robson M, et al. Transgenic mutant D567G but not wild-type human FSH receptor overexpression provides FSH-independent and promiscuous glycoprotein hormone Sertoli cell signaling. Am J Physiol Endocrinol Metab. 2009; 296:E1022-E1028. [PubMed: 19293333]

30. Peltoketo H, Strauss L, Karjalainen R, et al. Female mice expressing constitutively active mutants of FSH receptor present with a phenotype of premature follicle depletion and estrogen excess. Endocrinology. 2010; 151:1872-1883. [PubMed: 20172968]

31. Simoni M, Gromoll J, Höppner W, et al. Mutational analysis of the follicle-stimulating hormone $(\mathrm{FSH})$ receptor in normal and infertile men: identification and characterization of two 
discrete FSH receptor isoforms. J Clin Endocrinol Metab. 1999; 84:751-755. [PubMed: $10022448]$

32. Perez Mayorga M, Gromoll J, Behre HM, et al. Ovarian response to follicle-stimulating hormone (FSH) stimulation depends on the FSH receptor genotype. J Clin Endocrinol Metab. 2000; 85:3365-3369. [PubMed: 10999835]

33. Behre HM, Greb RR, Mempel A, et al. Significance of a common single nucleotide polymorphism in exon 10 of the follicle.stimulating hormone (FSH) receptor gene for the ovarian response to FSH: a pharmacogenetic approach to controlled ovarian hyperstimulation. Pharmacogenet Genomics. 2005; 15:451-456. [PubMed: 15970792]

* 34. Casarini L, Pignatti E, Simoni M. Effects of polymorphisms in gonadotropin and gonadotropin receptor genes on reproductive function. Rev Endocr Metab Disord. 2011; 12:303-321. [PubMed: 21912887] This recent review focuses on the effects of polymorphisms of the gonadotrophins and their receptor genes on reproductive functions of both male and female, and discusses their pathophysiological implications.

** 35. Altmäe S, Hovatta O, Stavreus-Evers A, Salumets A. Genetic predictors of controlled ovarian hyperstimulation: where do we stand today? Hum Reprod Update. 2011; 17:813-28. [PubMed: 21862569] Complete and recent systematic review focused on studies of genetic variation and its influence on controlled ovarian hyperstimulation $(\mathrm{COH})$ in in vitro fertilization (IVF) treatment.

* 36. Yao Y, Ma CH, Tang HL, Hu YF. Influence of follicle-stimulating hormone receptor (FSHR) Ser680Asn polymorphism on ovarian function and in-vitro fertilization outcome: a metaanalysis. Mol Genet Metab. 2011; 103:388-393. [PubMed: 21546300] The meta-analysis of several studies confirmed the significantassociation between the FSHRposition Asn680Ser Ser/ Ser homozygositywith higher basal level of FSH suggesting poorer ovarian response to exogenous FSH.

37. Greb RR, Grieshaber K, Gromoll J, et al. A common single nucleotide polymorphism in exon 10 of the human follicle stimulating hormone receptor is a major determinant of length and hormonal dynamics of the menstrual cycle. J Clin Endocrinol Metab. 2005; 90:4866-7482. [PubMed: 15886248]

38. Wang HS, Cheng BH, Wu HM, et al. A mutant single nucleotide polymorphism of folliclestimulating hormone receptor is associated with a lower risk of endometriosis. Fertil Steril. 2011; 95:455-457. [PubMed: 20817169]

39. Corbo RM, Gambina G, Broggio E, Scacchi R. Influence of variation in the follicle-stimulating hormone receptor gene (FSHR) and age at menopause on the development of Alzheimer's disease in women. Dement Geriatr Cogn Disord. 2011; 32:63-69. [PubMed: 21865747]

40. Ferlin A, Pengo M, Selice R, et al. Analysis of single nucleotide polymorphisms of FSH receptor gene suggests association with testicular cancer susceptibility. Endocr Relat Cancer. 2008; 15:429-437. [PubMed: 18430895]

41. Yang CQ, Chan KY, Ngan HY, et al. Single nucleotide polymorphisms of follicle-stimulating hormone receptor are associated with ovarian cancer susceptibility. Carcinogenesis. 2006; 27:1502-1506. [PubMed: 16574671]

42. Heubner M, Riemann K, Otterbach F, et al. The haplotype of two FSHR polymorphisms in ovarian cancer-a potential role of ethnology in risk modification. Gynecol Oncol. 2009; 112:486-489. [PubMed: 19147210]

43. Ludwig AH, Murawska M, Panek G, et al. Androgen, progesterone, and FSH receptor polymorphisms in ovarian cancer risk and outcome. Endocr Relat Cancer. 2009; 16:1005-1016. [PubMed: 19458022]

44. Nakayama T, Kuroi N, Sano M, et al. Mutation of the follicle-stimulating hormone receptor gene $5^{\prime}$-untranslated region associated with female hypertension. Hypertension. 2006; 48:512-518. [PubMed: 16864747]

** 45. Desai SS, Achrekar SK, Pathak BR, et al. Follicle-stimulating hormone receptor polymorphism (G-29A) is associated with altered level of receptor expression in Granulosa cells. J Clin Endocrinol Metab. 2011; 96:2805-2812. [PubMed: 21752882] This study demonstrated that women with AA-genotype for the FSHR position -29G/A exhibit the lowest mRNA and cell surface FSHR expression resulting ina poor ovarian response and requirement for higher amounts of exogenous FSH for ovulation induction. 
* 46. Achrekar SK, Modi DN, Meherji PK, et al. Follicle stimulating hormone receptor gene variants in women with primary and secondary amenorrhea. J Assist Reprod Genet. 2010; 27:317-326. [PubMed: 20237833] The AA-genotype for the FSHR position -29G/A is enriched among women with amenorrhea and is associated with increased serum FSH level in primary amenorrhea subjects.

47. Lend AK, Belousova A, Haller-Kikkatalo K, et al. Follicle-stimulating hormone receptor gene haplotypes and male infertility in Estonian population and meta-analysis. Syst Biol Reprod Med. 2010; 56:84-90. [PubMed: 20170288]

48. Kerns SL, Ostrer H, Stock R, et al. Genome-wide association study to identify single nucleotide polymorphisms (SNPs) associated with the development of erectile dysfunction in AfricanAmerican men after radiotherapy for prostate cancer. Int J Radiat Oncol Biol Phys. 2010; 78:1292-1300. [PubMed: 20932654]

49. Plunkett J, Doniger S, Orabona G, et al. An evolutionary genomic approach to identify genes involved in human birth timing. PLoS Genet. 2011; 7:e1001365. [PubMed: 21533219]

50. Sikaris K, McLachlan RI, Kazlauskas R, et al. Reproductive hormone reference intervals for healthy fertile young men: evaluation of automated platform assays. J Clin Endocrinol Metab. 2005; 90:5928-5936. [PubMed: 16118337]

51. Goodarzi MO, Dumesic DA, Chazenbalk G, Azziz R. Polycystic ovary syndrome: etiology, pathogenesis and diagnosis. Nat Rev Endocrinol. 2011; 7:219-231. [PubMed: 21263450]

52. Petríková J, Lazúrová I. Ovarian failure and polycystic ovary syndrome. Autoimmun Rev. Dec 2.2011 Epub ahead of print.

53. Kahsar-Miller M, Azziz R. The development of the polycystic ovary syndrome: family history as a risk factor. Trends Endocrinol Metab. 1998; 9:55-58. [PubMed: 18406241]

54. Valkenburg O, Uitterlinden AG, Piersma D, et al. Genetic polymorphisms of GnRH and gonadotropin hormone receptors affect the phenotype of polycystic ovary syndrome. Hum Reprod. 2009; 24:2014-2022. [PubMed: 19403562]

** 55. Chen ZJ, Zhao H, He L, et al. Genome-wide association study identifies susceptibility loci for polycystic ovary syndrome on chromosome 2p16.3, 2p21 and 9q33.3. Nat Genet. 2011; 43:5559. [PubMed: 21151128] The first genome-wide association study (GWAS) to identify susceptibility loci for PCOS in a large number of samples recruited from Chinese Han population.

56. Zhao H, Xu X, Xing X, et al. Family-based analysis of susceptibility loci for polycystic ovary syndrome on chromosome 2p16.3, 2p21 and 9q33.3. Hum Reprod. 2012; 27:294-298. [PubMed: 22081247]

* 57. Du J, Zhang W, Guo L, et al. Two FSHR variants, haplotypes and meta-analysis in Chinese women with premature ovarian failure and polycystic ovary syndrome. Mol Genet Metab. 2010; 100:292-295. [PubMed: 20399696] A meta-analysis showed that the FSHR Ala307-Ser680 genotype is associated with increased risk for polycystic ovarian syndrome (PCOS).

58. Overbeek A, Kuijper EA, Hendriks ML, et al. Clomiphene citrate resistance in relation to folliclestimulating hormone receptor Ser680Ser-polymorphism in polycystic ovary syndrome. Hum Reprod. 2009; 24:2007-2013. [PubMed: 19401323]

59. Burgers JA, Fong SL, Louwers YV, et al. Oligoovulatory and anovulatory cycles in women with polycystic ovary syndrome (PCOS): what's the difference? J Clin Endocrinol Metab. 2010; 95:E485-489. [PubMed: 20843954]

60. Dolfin E, Guani B, Lussiana C, et al. FSH-receptor Ala307Thr polymorphism is associated to polycystic ovary syndrome and to a higher responsiveness to exogenous FSH in Italian women. J Assist Reprod Genet. 2011; 28:925-930. [PubMed: 21792664]

61. Shelling AN. Premature ovarian failure. Reproduction. 2010; 140:633-641. [PubMed: 20716613]

62. Nelson LM. Clinical practice. Primary ovarian insufficiency. N Engl J Med. 2009; 360:606-614. [PubMed: 19196677]

** 63. Kim S, Pyun JA, Cha DH, et al. Epistasis between FSHR and CYP19A1 polymorphisms is associated with premature ovarian failure. Fertil Steril. 2011; 95:2585-2588. [PubMed: 21269619] Ninety-eight premature ovarian failure (POF) patients and 218 age-matched controls were screened for FSHR and Cyp19A1 polymorphisms. Women carrying a combination of Asn- 
allele for FSHR Asn680Ser and (C-T)+(C-C) for the Cyp19A1rs4646-rs10046 haplotype demonstrated higher risk for POF.

* 64. Rendina D, Gianfrancesco F, De Filippo G, et al. FSHR gene polymorphisms influence bone mineral density and bone turnover in postmenopausal women. Eur J Endocrinol. 2010; 163:165172. [PubMed: 20335500] Postmenopausal women carrying FSHR Asn680Ser Asn/Asn genotype had significantly higher risk of femoral neck and total body osteoporosis when compared to Ser/Ser carriers.

* 65. Morón FJ, Ruiz A. Pharmacogenetics of controlled ovarian hyperstimulation: time to corroborate the clinical utility of FSH receptor genetic markers. Pharmacogenomics. 2010; 11:1613-1618. [PubMed: 21121812] The detailed review on the FSHR position Asn680Ser and other genetic markers involved in $\mathrm{COH}$ response.

66. Daelemans C, Smits G, de Maertelaer V, et al. Prediction of severity of symptoms in iatrogenic ovarian hyperstimulation syndrome by follicle-stimulating hormone receptor Ser680Asn polymorphism. J Clin Endocrinol Metab. 2004; 89:6310-6315. [PubMed: 15579795]

67. Achrekar SK, Modi DN, Desai SK, et al. Poor ovarian response to gonadotrophin stimulation is associated with FSH receptor polymorphism. Reprod Biomed Online. 2009; 18:509-515. [PubMed: 19400992]

* 68. Gerasimova T, Thanasoula MN, Zattas D, et al. Identification and in vitro characterization of follicle stimulating hormone (FSH) receptor variants associated with abnormal ovarian response to FSH. J Clin Endocrinol Metab. 2010; 95:529-536. [PubMed: 20061434] The results of this study indicated that splicing variants of FSHR coexisting with wild-type FSHR variant are associated with deviations from the normal ovarian response to exogenous FSH during fertility treatment.

69. Foresta C, Selice R, Ferlin A, et al. Hormonal treatment of male infertility: FSH. Reprod Biomed Online. 2007; 15:666-672. [PubMed: 18062863]

70. Foresta C, Selice R, Garolla A, Ferlin A. Follicle-stimulating hormone treatment of male infertility. Curr Opin Urol. 2008; 18:602-607. [PubMed: 18832946]

** 71. Selice R, Garolla A, Pengo M, et al. The response to FSH treatment in oligozoospermic men depends on FSH receptor gene polymorphisms. Int J Androl. 2011; 34:306-312. [PubMed: 20569270] Only subjects carrying Ser-allele of the FSHR Asn680Ser polymorphism showed significant increase in total sperm count, sperm concentration, forward motility, percentage of normal morphology forms and total motile sperm.

** 72. Bouvattier C, Maione L, Bouligand J, et al. Neonatal gonadotropin therapy in male congenital hypogonadotropic hypogonadism. Nat Rev Endocrinol. Oct 18.2011 doi: 10.1038/nrendo. 2011.164. Recent review regarding genetics, ontogenesis and efficient treatment of the deficiency in GnRH and pituitary gonadotrophins - congenital hypogonadotropic hypogonadism (CHH).

73. Raivio T, Wikström AM, Dunkel L. Treatment of gonadotropin-deficient boys with recombinant human FSH: long-term observation and outcome. Eur J Endocrinol. 2007; 156:105-111. [PubMed: 17218732] 


\section{Key points}

- The efficiency of FSH action is regulated by threemain factors-the serum levels of circulating hormone, its intrinsic bioactivity and the efficacy of FSHR signal transduction in testicular and ovarian target cells

- Four common variants in $F S H B / F S H R$ were shown to exhibit significant effect on FSH action: linked FSHR variants Thr307Ala and Asn680Ser determining common protein isoforms, andgene expression affectingpolymorphisms FSHR29G/A and $F S H B-211 \mathrm{G} / \mathrm{T}$

- In women, theFSHR Thr307Ala/Asn680Serpolymorphisms show consistent predictive value for estimating the most optimal $\mathrm{rFSH}$ dosage in $\mathrm{COH}$, and these variants also exhibit a potential for the pharmacogenetic assessmentin PCOS patients

- Recently, theFSHR-29G/A polymorphism was shown to modulateto ovarian response to $\mathrm{COH}$

- In men,pilot studieshave demonstrated the FSHB-211 TT-homozygotes with genetically determined low FSH aspotentially the best responders to rFSH treatment, and the response may also be modulated by FSHRpolymorphisms 

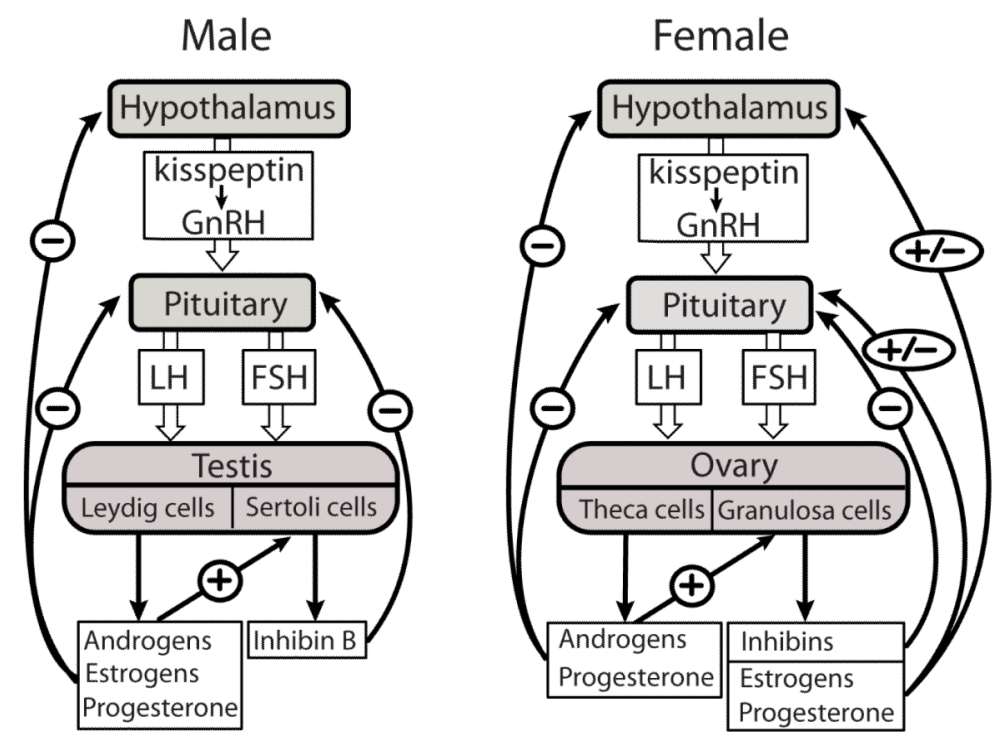

Figure 1.

Schematic feedback control of the human hypothalamic-pituitary-gonadal (HPG) axis. In males and females, kisspeptin-triggeredpulsatile secretion of gonadotropin-releasing hormone $(\mathrm{GnRH})$ from the hypothalamus stimulates the release of pituitary gonadotrophins (FSH and LH). FSH binds to its receptors located in testicular Sertoli and ovarian granulosa cells, and stimulates the secretion of inhibins that suppress FSH production from the pituitary. LH interacts with receptors on testicular Leydig cells and ovarian theca and granulosa cells, thereby stimulating the production of steroid hormones that stimulate their target cells in the reproductive tract.Steroid hormones (androgens, estrogens, progesterone) produced by ovaries and testesexert theirnegative (males) and negativeand positive (females)endocrine feedback to hypothalamic-pituitary levelby regulating thesynthesis and secretion of kisspeptin, GnRH and gonadotrophins. 


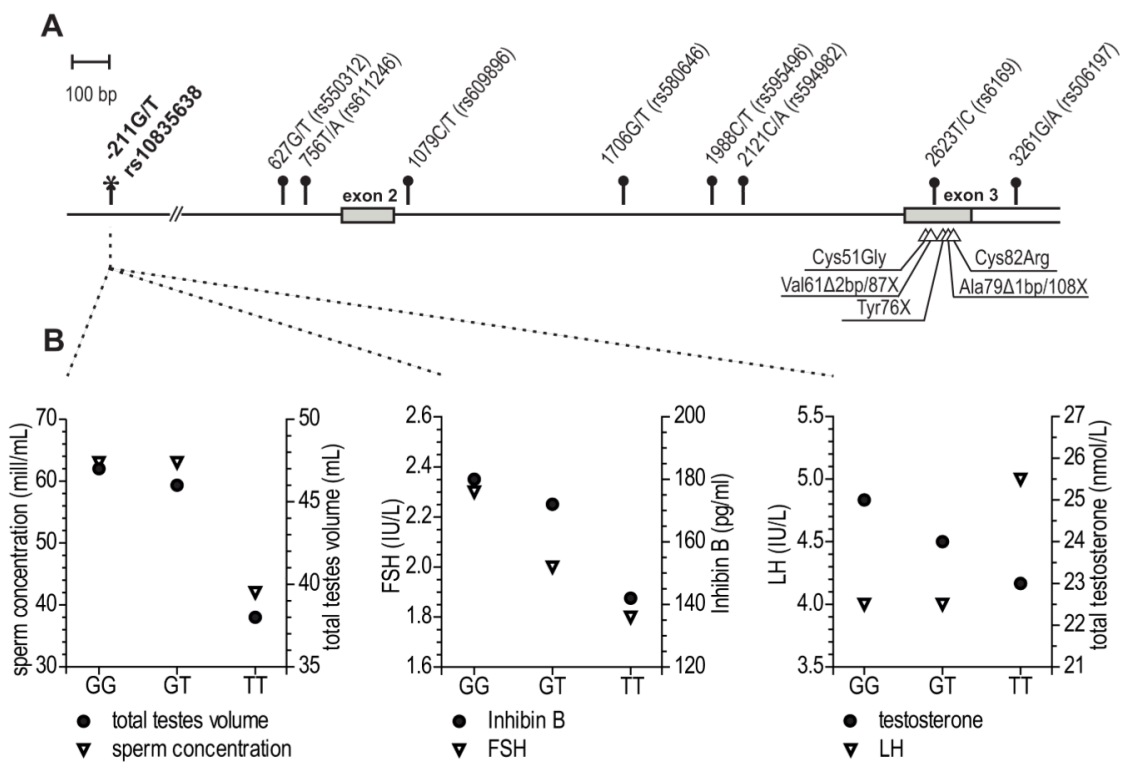

Figure 2.

(A) Genetic variation in the $F S H B$ gene;(B) Phenotypic effects of the carrier status of alternative genotypes of FSHBpromoter polymorphism -211G/T (rs10835638) on male reproductive parameters

(A) FSHBtranscribedregions are indicated by boxes and translated sequencesaredenoted by grey areas. Common polymorphisms (minor allele frequency $>10 \%$ ) that form two major gene haplotypes (96.6\% of analysed samples[17]) are shown as circle-headed bars and their positionsare denoted relative to the $F S H B$ transcription start-site. The $F S H B-211 \mathrm{G} / \mathrm{T}$ promoter SNP is indicated by an asterisk. FSHB mutations identified in infertile patientsare shown by triangles and their localization in the mature FSH beta peptide is indicated. (B) Effect of the $F S H B$ gene promoter polymorphism -211G/T (rs10835638) on male hormonal and testicular parameters: total testis volume and sperm concentration (left panel), serum FSH and Inhibin B levels (middle panel), serum LH and total testosterone levels (right panel). Individuals are subgrouped according to their FSHB promoter position -211G/ $\mathrm{T}$ genotype. Median values of reproductive parameters are presented based on Grigorova et al. $\left[20^{* *}\right]$. 


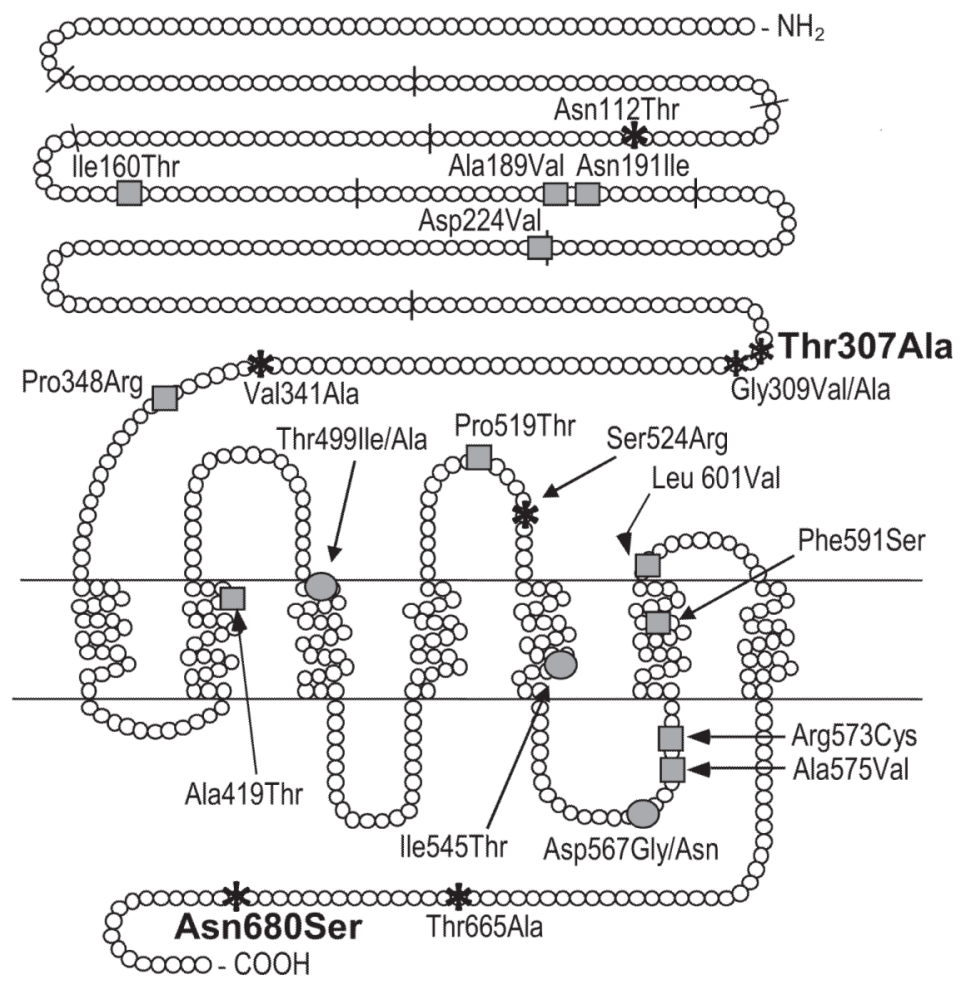

Figure 3.

The distribution of currently known functional polymorphisms, and activating and inactivating mutations across the human FSHR gene. The FSHR exon boundaries are marked with short bars striking through the protein sequence. Greycircles depict the activating, greysquares inactivating mutations, and the asterisks the polymorphisms. The two polymorphisms Thr307Ala and Asn680Ser with currently known pharmacogenetic significance and exhibiting linkage disequilibrium in most populations are marked in bold. An additionalpolymorphism that has been indicated to have pharmacogenetic potential is $F S H R-29 \mathrm{G} / \mathrm{A}$ located in $5^{\prime}$-untranslated region and thus, not presented in this figure. 